\title{
Soil Respiration and Its Effect Factors at Different Succession Stages during the Growing Season of Larix Gmelinii Forest in Great Xing' an Mountain
}

\author{
Xi Liu ${ }^{1}$ and Jingwei Liu ${ }^{2 *}$ \\ ${ }^{1,2}$ Northeast Forestry University \\ 1113313482@qq.com, ${ }^{2} 754220456 @ q q . c o m$
}

\begin{abstract}
With Li-8100 chamber, the soil respiration rates in different succession stages of Larix gmelinii plantation in Great Xing' an Mountains was measured from June to October, 2014. Results show that the variations of soil respiration can be expressed as a onehumped curve. The maximum of soil respiration rate occurs from July for early and midsuccession stage to August for late succession. Soil respiration rate varies from 1.2 to $4.6 \mu \mathrm{mol} \cdot \mathrm{m}-2 \cdot \mathrm{s}-1$ with mean value of $2.76 \mu \mathrm{mol} \cdot \mathrm{m}-2 \cdot \mathrm{s}-1$ for early succession, 1.5 to $5.6 \mu \mathrm{mol} \cdot \mathrm{m}-2 \cdot \mathrm{s}-1$ with mean value of $3.17 \mu \mathrm{mol} \cdot \mathrm{m}-2 \cdot \mathrm{s}-1$ for mid-succession, and 1.8 to $4.1 \mu \mathrm{mol} \cdot \mathrm{m}-2 \cdot \mathrm{s}-1$ with mean value of $2.89 \mu \mathrm{mol} \cdot \mathrm{m}-2 \cdot \mathrm{s}-1$ for late succession. Soil temperature is the main factor to affect soil respiration and there is a significant correlation between soil respiration and the soil temperature at $10 \mathrm{~cm}$ depth in all different succession forests, but less correlation is observed between soil respiration and soil water content.
\end{abstract}

Keywords: Soil Respiration, Succession Stages, Soil Temperature, Moisture Content, Great Xing' an Mountains, Larix gmelinii Forest

\section{Introduction}

The forest soil carbon pool accounts for about $73 \%$ of the soil carbon [1]. Thus, relatively small change of forest soil carbon pool may have an important role in regulating the global carbon balance. Understanding soil organic carbon fractions and their responses to soil temperature and moisture content will help to reveal the dynamic and mechanism of soil carbon pool [2-3].

It is well known that succession and forest age can lead to the recovery of deteriorated soil properties [4-5], for this reason, it is essential to understand the succession mechanism of cognitive effect on soil carbon flux. Recently, Chinese scientists have increased the attention paid to the succession of secondary forests [6]. While a lot of research has focused on changes in the aboveground vegetation of secondary forests [7], few studies have focused on changes to the soil it self [8], although studies have already been done on soil properties. Furthermore, little investigation has been carried out on soil carbon flux at different succession stages of these secondary forests.

Great Xing' an Mountain is the most important forest station in the highest latitude in China; however, there has little research on the carbon fluxes of various forest succession stages. In this article, we measured soil respiration using Li-8100, soil temperature at $10 \mathrm{~cm}$ depth and water content from different succession forests during their growing season to illustrate the soil respiration change tendency and its effect factors.

\footnotetext{
${ }^{*}$ Corresponding Author
} 


\section{Materials and Methods}

\subsection{Study Areas}

The study area locates in the Tayuan forest station of Great Xing' an mountains $\left(50^{\circ} 10^{\prime}-53^{\circ} 33^{\prime} \mathrm{N} 121^{\circ} 12^{\prime}-127^{\circ} 00^{\prime} \mathrm{E}\right)$ lie in Northeast China. The regional climate is within the cool temperate zone with average annual temperature of $-2.4^{\circ} \mathrm{C}$, extreme minimum temperature $-47{ }^{\circ} \mathrm{C}$, the highest temperature is $33{ }^{\circ} \mathrm{C}$, and annual precipitation of 350 $500 \mathrm{~mm}$. The dominant vegetation of the area is boreal coniferous forests. The dominant species include larch (Larix gmelinni), Pine (Pinus sylvestris var. mongolica), birch (Betula platyphylla), shrubs (Vaccinium spp., Rhododendron dauricum and Ledum palustre), and grass (Carex tristachya) forming landscapes with various forest types.

This research selected the Ledum palustre- Larix gmelinni virgin forest as the late succession stage, with canopy density of 0.9. Different succession stages of site conditions and stand characteristics are shown in Table 1.

\section{Table1. Site Conditions and Stand Characteristics under Different Succession Stages}

\begin{tabular}{|c|c|c|c|c|c|c|}
\hline $\begin{array}{l}\text { Succession } \\
\text { stages }\end{array}$ & Aspect & $\begin{array}{c}\text { Slope } \\
\left({ }^{\circ}\right. \\
)\end{array}$ & $\begin{array}{l}\text { Soil } \\
\text { type }\end{array}$ & $\begin{array}{c}\text { DBH } \\
( \\
\mathrm{cm} \\
)\end{array}$ & $\begin{array}{l}\text { Height } \\
(\mathrm{m} \\
)^{2}\end{array}$ & $\begin{array}{l}\text { Canopy } \\
\text { density }\end{array}$ \\
\hline $\begin{array}{c}\text { Early } \\
\text { succession }\end{array}$ & South & 6 & $\begin{array}{l}\text { Brown } \\
\text { forest }\end{array}$ & 11 & 8 & 0.4 \\
\hline $\begin{array}{c}\text { Mid- } \\
\text { succession }\end{array}$ & South & 8 & $\begin{array}{l}\text { Brown } \\
\text { forest }\end{array}$ & 9 & 10.5 & 0.6 \\
\hline $\begin{array}{c}\text { Late } \\
\text { succession }\end{array}$ & East & 10 & $\begin{array}{l}\text { Brown } \\
\text { forest }\end{array}$ & 21 & 28 & 0.9 \\
\hline
\end{tabular}

\subsection{Methods}

2.2.1. Soil Respiration Measurement: Soil respiration was measured using a Li-8100 soil Co2 flux system during the frowning season from early June to late October in 2014. Five polyvinyl chloride (PVC) collars $(10 \mathrm{~cm}$ inside diameter, $6 \mathrm{~cm}$ height), in each succession forest (three plots with $20 * 20 \mathrm{~m}$ were settled) were inserted $8 \mathrm{~cm}$ into the soil and keep the litter as natural. Soil collar were placed in the soil at least $24 \mathrm{~h}$ before measurements to avoid influence of soil disturbance and root injury on the measurements. Note that all PVC collars were left in the same locations thought the growing period. Soil $\mathrm{CO}_{2}$ effluxes were measured twice a month and five times during measurement day (twice during night and three times during day). Respiration rates were calculated as means of three plots for each succession stand.

2.2.2. Data Analysis: Single factor and multiple comparison and meteorological factors were analyzed by SPSS 11.0, Excel for regression analysis and mapping.

\section{Results}

\subsection{Various of Larix Gmelinii Forest Soil Respiration during Different Succession Stages in the Growing Season}

Soil respiration has obvious seasonal variation in most ecosystems. In temperate forests, soil respiration was single-peak curve changes, from January to early growing season, soil respiration rate increased gradually, soil respiration grew fast 
when growing season began, and reached the maximum value in July and August, at end of growing season (October), soil respiration rate gradually reduced, the winter minimum and relatively stable.

Figure 1, represents the various of soil respiration in Larix gmelinii forest during different succession stages in the growing season. Temperature rose again and soil began to thaw since June. But soil respiration rate was relatively low for high soil water content and low temperature. Temperature in July and August was the highest and rainy season came, environment of soil was high temperature and high water content which offered a preferable place for soil microorganism and promote the soil respiration rate, soil respiration reached the peak of the year and then fell down gradually during late September and October for lower soil temperature and moisture content at $10 \mathrm{~cm}$ depth.

In different succession stages, the peak value of soil respiration rate appeared slightly different. In the early and mid-succession stages, the peak value of soil respiration appeared earlier (in late July), late succession appeared in late August. Soil respiration rate in early and mid-succession stages was higher than late succession during early growing season (June -August), while adversely during the late growing season. The ranges of different soil respiration rate change with various succession stages are as follows: early succession soil respiration is 1.2$4.6 \mu \mathrm{mol} \cdot \mathrm{m}-2 \cdot \mathrm{s}-1$ with the average value of $2.76 \mu \mathrm{mol} \cdot \mathrm{m}-2 \cdot \mathrm{s}-1$, mid-succession $1.5-5.6 \mu \mathrm{mol} \cdot \mathrm{m}-2 \cdot \mathrm{s}-1$ with average of $3.17 \mu \mathrm{mol} \cdot \mathrm{m}-2 \cdot \mathrm{s}-1$, late succession 1.8 $4.1 \mu \mathrm{mol} \cdot \mathrm{m}-2 \cdot \mathrm{s}-1$ with average of $2.89 \mu \mathrm{mol} \cdot \mathrm{m}-2 \cdot \mathrm{s}-1$. Variation range of soil respiration rate in early succession was $254 \%$, mid-succession of $273 \%, 128 \%$ of late succession. During the period of observation, soil respiration rate change $26 \%$ and $45 \%$ higher in the early stage and mid stage of succession than late succession and soil respiration rate was 1.2 to 1.3 times higher than the climax.

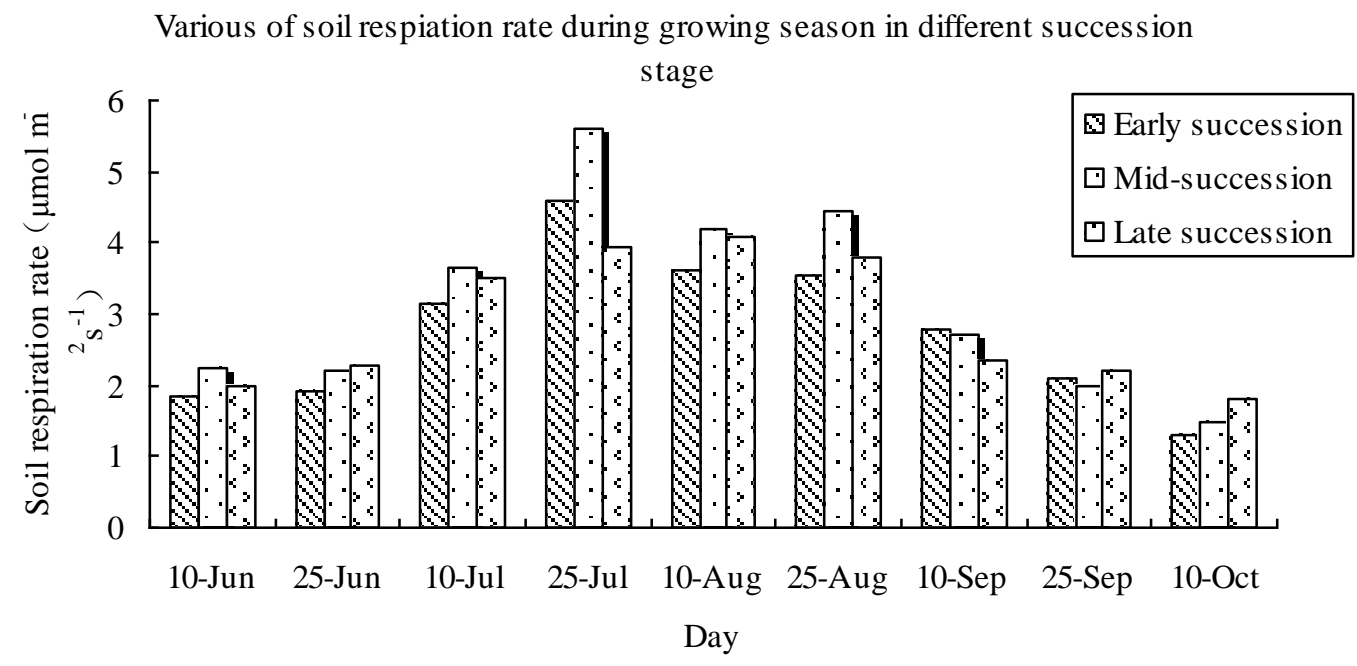

\section{Figure1. Dynamic Change of Soil Respiration Rate in Different Succession Stages of Larix Gemelinni Forest during the Growing Season}

\subsection{Relationship between Soil Respiration and Hydrothermal Factor}

3.2.1. Seasonal Change of Soil Temperature and Moisture Content during Different Succession Stages: variation range of soil temperature at $10 \mathrm{~cm}$ depth was $3.69-23.42^{\circ} \mathrm{C}$, and the change trend of the curve was unmoral type. The highest temperature appeared in the mid growing season (July) and the values were different for different succession stages, for example, $22.02^{\circ} \mathrm{C}$ for early succession, $23.42{ }^{\circ} \mathrm{C}$ for mid-succession and $14.02{ }^{\circ} \mathrm{C}$ for late succession. The lowest 
temperature appeared in late growing season (late October), $9.69{ }^{\circ} \mathrm{C}$ for early succession, $11.1{ }^{\circ} \mathrm{C}$ for mid-succession and $3.69{ }^{\circ} \mathrm{C}$ for late successions. Compared temperature in different succession stages of the same time period, no difference between the early and mid-succession stage, but significant differences at late succession $(\mathrm{p}<0.05)$ (Figure 2).

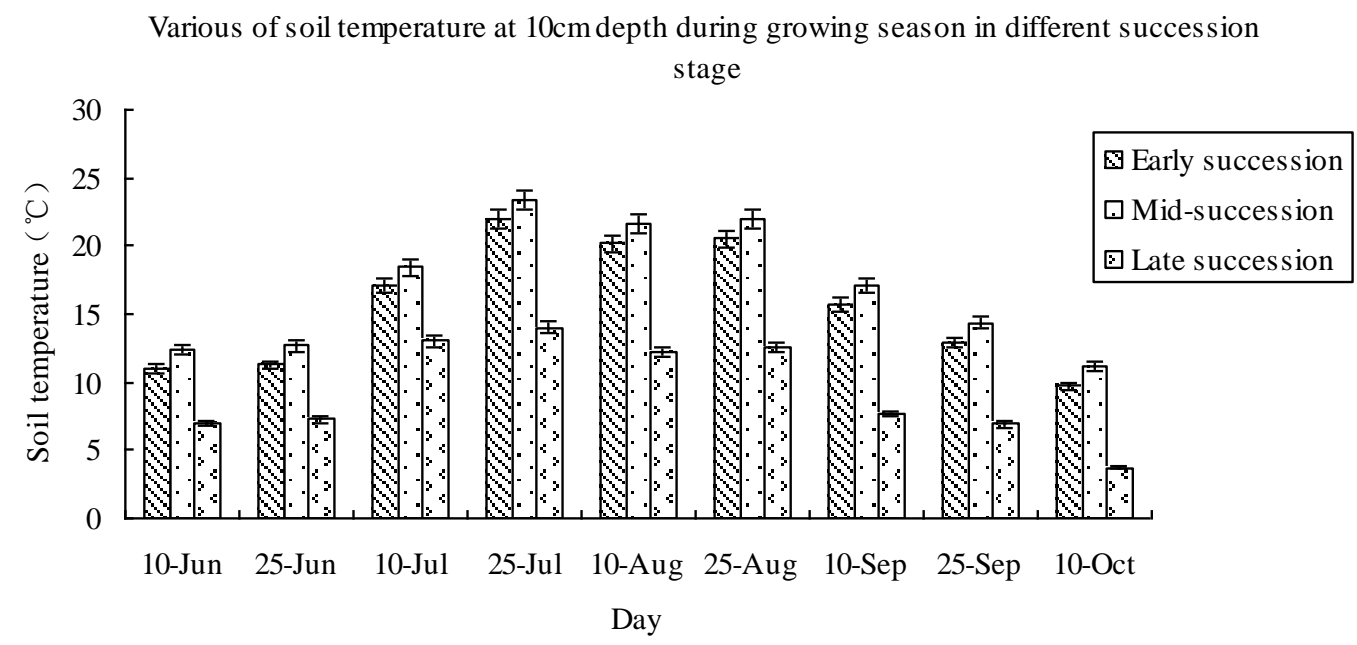

\section{Figure2. Dynamics of Soil Temperature at $10 \mathrm{~cm}$ Depth of Larix Gmelinni Forest at Different Succession Stages in the Growing Season}

Amplitude of different succession stages of soil water content $(0$ to $10 \mathrm{~cm})$ was bigger, $2.05-37.03 \%$ for early succession, $5.05-40.03 \%$ for mid-succession, 15 $50.03 \%$ for late succession. Soil moisture content changed as a wave shape with the higher value in June, July and September, the lowest in October (Figure 3).

Various of soil water content at 0-10cm depth during growing season in different succession stage

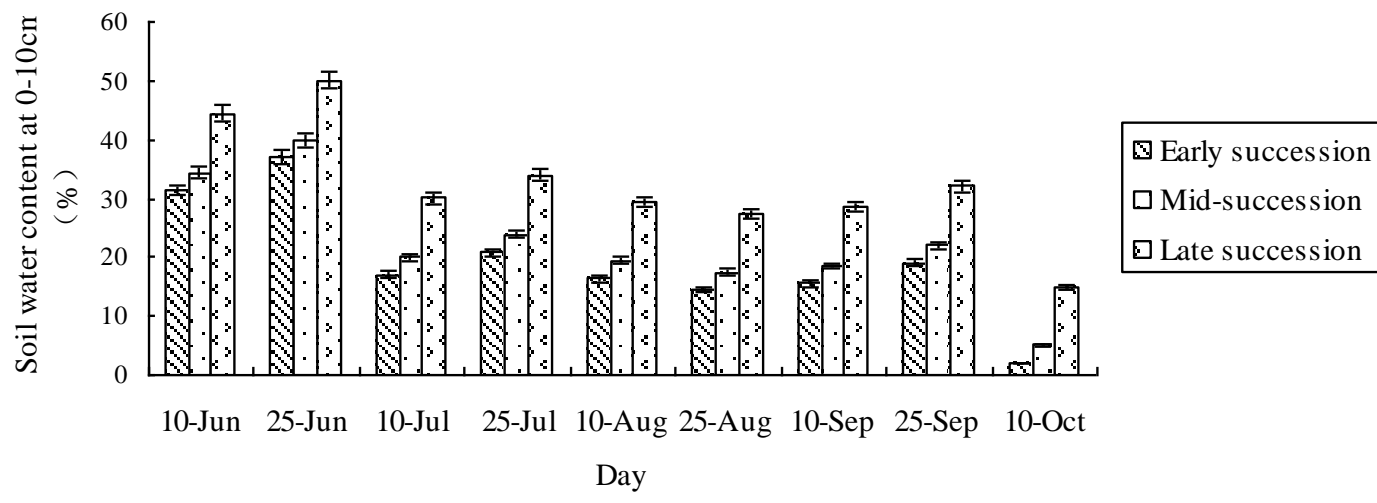

Figure 3. Dynamics of Soil Water Content at $10 \mathrm{~cm}$ Depth of Larix Gmelinni Forest at Different Succession Stages in the Growing Season

3.2.2. Relationships between Soil Respiration of Different Succession Stages and Hydrothermal Factors: there are many factors that affect the soil respiration rate, for example, Burton, AJ studied the relationship between soil respiration and soil nitrogen content and results showed that they had obvious relationship. Gough and Seeker found that existed significant positive correlation between soil respiration and soil carbon content at $20 \mathrm{~cm}$ depth. Study of $\mathrm{Xu}$ and Qi showed that soil 
respiration rate had positive relationship with soil organic matter content, total nitrogen, available phosphorus, exchangeable magnesium, and negative correlation with the soil PH and bulk density. Our study only discussed soil temperature and soil water content at $10 \mathrm{~cm}$ depth that affected soil respiration in different succession stage of Larix gmelinii forest. The study found that soil respiration had good relationship with soil temperature index regression $\left(\mathrm{R}^{2}\right.$ values were greater than 0.8 ), but no significant relationship with soil water content (Figure 4). Soil temperature is the main factor that affects soil respiration, which can explain $89 \%$ of soil respiratory change for early succession, $92 \%$ for mid-succession and $88 \%$ for late succession.
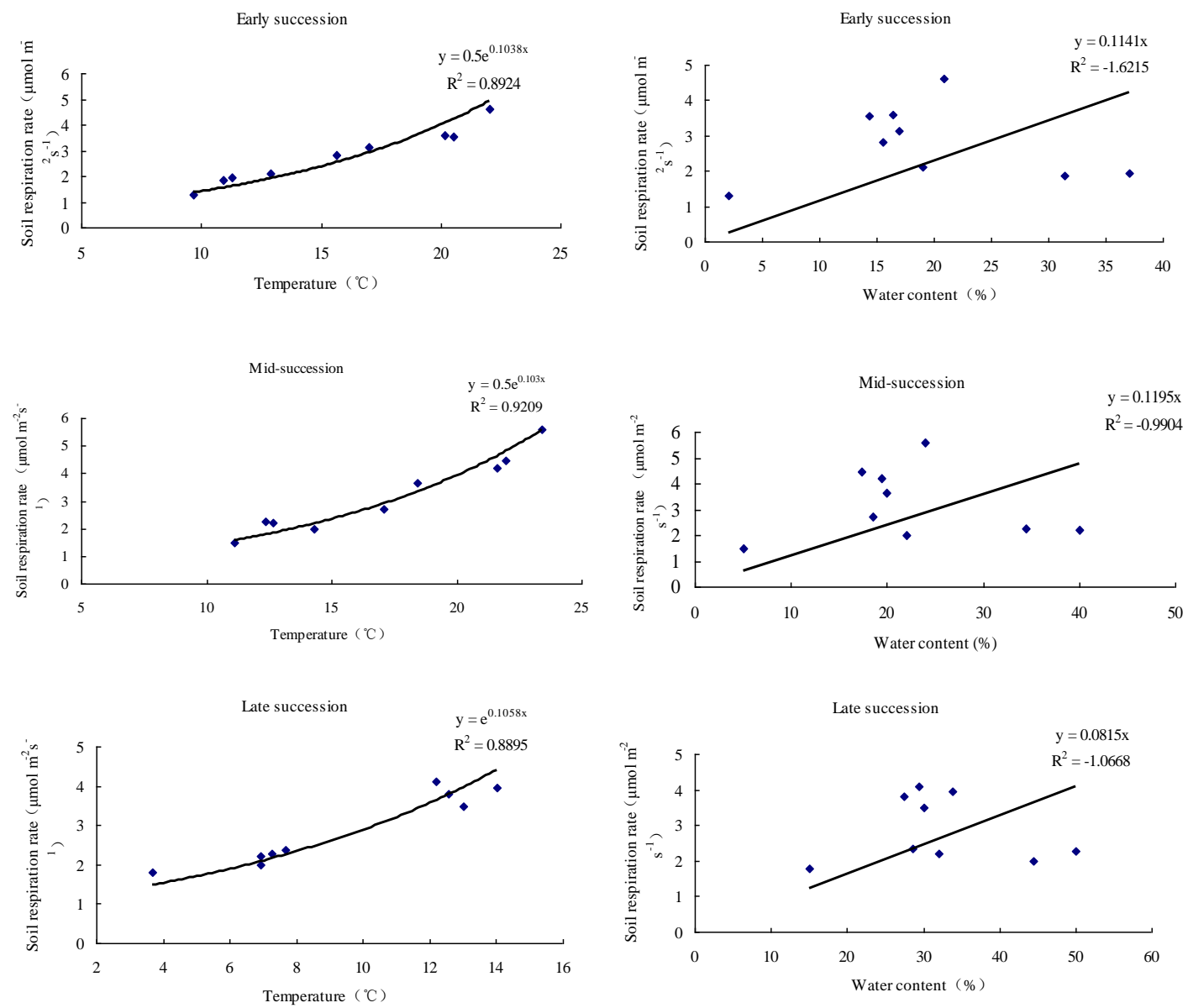

\section{Figure 4. Relationships between Soil Respiration and Soil Temperature and Water Content at 0-10 cm Depth of Larix Gmelinni Forest at Different Succession Stages}

\section{Discussions}

There exists an obvious seasonal change in soil respiration of different succession stage in Great Xing' an Mountain, it has the same changing trend with soil temperature at $10 \mathrm{~cm}$ depth and has unmoral type curve. Over the study period, the maximum soil respiration rate occurred from July with $4.6 \mu \mathrm{mol} \cdot \mathrm{m}-2 \cdot \mathrm{s}-1$ for early succession stage and $5.6 \mu \mathrm{mol} \cdot \mathrm{m}-2 \cdot \mathrm{s}-1$ for mid-succession stage to August with $4.1 \mu \mathrm{mol} \cdot \mathrm{m}-2 \cdot \mathrm{s}-1$ for late succession stage. Soil respiration rate varied from 1.2 to $4.6 \mu \mathrm{mol} \cdot \mathrm{m}-2 \cdot \mathrm{s}-1$ with the mean value of $2.76 \mu \mathrm{mol} \cdot \mathrm{m}-2 \cdot \mathrm{s}-1$ for early succession, 1.5 to $5.6 \mu \mathrm{mol} \cdot \mathrm{m}-2 \cdot \mathrm{s}-1$ with the mean value of $3.17 \mu \mathrm{mol} \cdot \mathrm{m}-2 \cdot \mathrm{s}-1$ for mid- 
succession, and 1.8 to $4.1 \mu \mathrm{mol} \cdot \mathrm{m}-2 \cdot \mathrm{s}-1$ with the mean value of $2.89 \mu \mathrm{mol} \cdot \mathrm{m}-2 \cdot \mathrm{s}-1$ for late succession. The amplitude of variation of soil respiration rate was 1.2-1.3 times higher for early and mid-succession than late succession.

There are many studies about the effects of soil temperature and soil water content on soil respiration. Results showed difference according to different climatic zones, since different forest ecosystems have different responding mechanisms to soil temperature and soil water content. Soil temperature was the main factor to affect soil respiration and there was a significant correlation between soil respiration and the soil temperature at $10 \mathrm{~cm}$ depth in all different succession forests, but less correlation was observed between soil respiration and soil water content. This result was agreed with Tang et. al., 2009,Wang G.H.,2009, Sheng et. al., 2010, Fan Y.X., 2011,.This may be related to the soil moisture content can not directly change the soil respiration flux, but indirectly by the microbial activity, plants fine root respiration, layer decomposition rate, etc.,

\section{Acknowledgments}

This research was supported by the "Fundamental Research Funds for the Central Universities", 2572014B19 and Research of ecosystem services and ecological civilization construction for state-owned forest in the northeast of China, "2015-01".

\section{References}

[1] W. M. Post and W. R. Emanuel, "Soil Carbon Pools and World Life Zones", Nat., vol. 298, no. 2, (1982), pp. 156-159.

[2] R. Laik, K. Kumar, D. K. Das and O. P. Chaturved, "Labile Soil Organic Matter Pools in a Calciorthent after 18 Years of Afforestation by different plantations", Appl. Soi. Eco., vol. 42, (2009), pp. 71-78.

[3] W. Gong, T. X. Hu and J. Y. Wang, "Soil Carbon Pool and Fertility under Natural Evergreen Broadleaved Forest and its Artificial Regeneration Forests in Southern Sichuan Province", Act. Eco. Sin., vol. 28, (2008), pp. 2536-2545.

[4] G. M. Jia, J. Cao, C. Y. Wang and G. Wang, "Microbial Biomass and Nutrients in Soil at the Different Stages of Secondary Forest Succession in Ziwulin, Northwest China", For. Eco.\& Man., vol. 217, (2005), pp. 117-125.

[5] S. W. Zhao, Y. G. Zhao and J. S. Wu, "Quantitative Analysis of Soil Pores under Natural Vegetation Succession on the Loess Plateau”, Sci. Chi. Ear. Sci., vol. 53, (2010), pp. 617-625.

[6] J. M. Cheng, J. Cheng, H. B. Shao, L. P. Zhao and X. M. Yang, "Soil Seed Banks and Forest Succession Direction Reflect Soil Quality in Ziwuling Mountain, Loess Plateau, China”, Clean-Soi. Air Wat., vol. 40, (2012), pp. 140-147.

[7] K. B. Wang, R. X. Shao and Z. P. Shangguan, "Changes in Species Richness and Community Productivity during Succession on the Loess Plateau (China)”, Pol. Jou. of Eco., vol. 58, (2012), pp. 549-558.

[8] H. Y. Zou, G. B. Liu and H. S. Wang, "The Vegetation Development in North Ziwuling Forest Region in Last Fifty Years", Act. Bot. Boreali- Occ. Sin., vol. 22, no. 22, (2012), pp. 1-8. 